\title{
GAMBARAN KADAR HEMOGLOBIN DAN TROMBOSIT PADA PASIEN TUBERKULOSIS PARU DI RSUP. PROF. DR. R. D. KANDOU MANADO PERIODE JANUARI 2014 -DESEMBER 2014
}

\author{
${ }^{1}$ Nathalin M. Lasut \\ ${ }^{2}$ Linda W. A. Rotty \\ ${ }^{2}$ Efata B. I. Polii \\ ${ }^{1}$ Kandidat Skripsi Fakultas Kedokteran Universitas Sam Ratulangi Manado \\ ${ }^{2}$ Bagian/SMF Ilmu Penyakit Dalam RSUP Prof. Dr. R. D. Kandou Manado \\ Email : nathalinlasut12069@gmail.com
}

Latar Belakang: Tuberkulosis merupakan masalah kesehatan global dan penyebab kematian tersering oleh infeksi setelah HIV. Penurunan kadar Hb dibawah nilai normal didefinisikan sebagai anemia, anemia sendiri adalah fitur utama pada pasien dengan infeksi bakteri. Trombositosis reaktif dapat ditemukan dalam sejumlah situasi klinis termasuk penyakit menular.

Tujuan: Untuk mengetahui kadar hemoglobin dan jumlah trombosit pada pasien tuberculosis paru di RSUP Prof. Dr. R. D. Kandou Manado periode Januari 2014 - Desember 2014

Metode: Penelitian ini menggunakan metode penelitian deskriptif retrospektif.

Hasil: Dari 67 pasien, jumlah pasien dengan kadar hemoglobin dibawah nilai normal atau anemia sebanyak 44 pasien (65,67\%) dansebanyak 23 pasien (34,33\%) tidak mengalami anemia. Jumlah pasien yang mengalami trombositopenia sebanyak 4 pasien (5,97\%), pasien dengan kadar trombosit normal sebanyak 50 pasien (74,62\%), dan yang mengalami trombositosis sebanyak 13 pasien (19,40\%).

Kesimpulan: Kadar hemoglobin pada penderita TB paru ditemukan terbanyak dengan kadar $\mathrm{Hb}$ yang rendah atau anemia, sedangkan jumlah trombosit pada penderita TB paru ditemukan terbanyak dengan jumlah trombosit normal.

Kata kunci: Tuberkulosis paru, Hemoglobin, Trombosit

Background: Tuberculosis remain a major health problem and second most common cause of death by infection after HIV. The decrease of Hb levels below normal value is defined as anemia, anemia itself is a major feature in patients with bacterial infection. Reactive thrombocytosis can be found in a number of clinical situations including infectious diseases.

Objective: To determine hemoglobin levels and platelet counts in patients with pulmonary tuberculosis at Prof. Dr. R. D. Kandou Manado general hospital periods January 2014 December 2014.

Method: This research uses descriptive retrospective study design.

Results: Among 67 patients, number of patients with hemoglobin levels below the normal value or anemia are 45 patients $(65,67 \%)$ and 23 patients $(34,33 \%)$ are not anemic. Number of patients with thrombocytopenia are 4 patients $(5,97 \%)$, patients with normal number of platelets are 50 patients (74,62\%) and number of patients with thrombocytosis are 13 patients $(19,40 \%)$.

Conclusion: Hemoglobin levels in patients with pulmonary TB are found most below the normal value or anemia while the number of platelets in patients with pulmonary TB are found most normal platelet counts.

Keyword: Pulmonary tuberculosis, Hemoglobin, Platelets 
Tuberkulosis (TB) merupakan infeksi paru - paru yang ditandai oleh infiltrat paru dan pembentukan granuloma kaseosa, fibrosis, dan kavitas. Tuberkulosis dapat disebabkan akibat pajanan terhadap basil tahan asam Mycrobacterium tuberculosis. Meskipun tempat infeksi primer di paru - paru, mikrobakteri juga sering ditemukan di bagian tubuh lainnya. ${ }^{1}$

Tuberkulosis masih merupakan masalah utama kesehatan global dan penyebab kematian tersering oleh infeksi setelah HIV. Berdasarkan laporan World Health Organization (WHO) pada tahun 2013 prevalensi kasus TB terdapat hampir 9 juta kasus TB dan 1,5 juta kematian akibat TB serta 360.000 kematian dengan human immunodeficiency virus (HIV) positif. World Health Organization pada tahun 2013 memperkirakan terdapat 3,3 juta kasus TB dan 510.000 kematian di kalangan perempuan, serta terdapat 550.000 kasus TB dan 80.000 kematian pada anak-anak. ${ }^{2}$

Berdasarkan data Riskesdas 2013 prevalensi penduduk Indonesia yang didiagnosis TB paru oleh tenaga kesehatan tahun 2013 adalah 0.4 persen, lima provinsi dengan TB paru tertinggi adalah Jawa Barat $(0.7 \%)$, Papua (0.6\%), DKI Jakarta (0.6\%), Gorontalo (0.5\%), Banten (0.4\%), dan Papua Barat $(0.4 \%){ }^{3}$

(ubah sumber)Sel darah merah berfungsi mengangkut $\mathrm{O}_{2}$ ke jaringan dan mengembalikan $\left(\mathrm{CO}_{2}\right)$ dari jaringan ke paru, untuk mencapai hal ini sel darah merah mengandung protein spesial yaitu hemoglobin. Tiap sel darah merah mengandung 640 juta molekul hemoglobin (Hb). Nilai umum kadar Hb adalah kurang dari 13,5 g/dL pada pria dewasa dan kurang dari 11,5 g/dL pada wanita dewasa, penurunan kadar $\mathrm{Hb}$ dibawah nilai normal didefinisikan sebagai anemia. ${ }^{4}$ Anemia adalah fitur utama pada pasien dengan infeksi bakteri, terutama infeksi yang berlangsung lebih dari satu bulan, termasuk tuberkulosis paru di mana mekanisme yang tepat dari anemia pada TB paru tidak jelas diketahui. ${ }^{5,6}$ Pada pasien TB paru meningkatnya level $\mathrm{Hb}$ digunakan sebagai penanda respon pengobatan. $^{7}$

Trombosit mempunyai peran penting dalam hemostasis yaitu pembentukan dan stabilisasi sumbat trombosit. Pembentukan sumbatan trombosit terjadi melalui beberapa tahap yaitu adesi trombosit, agregasi trombosit dan reaksi pelepasan. ${ }^{8}$ Trombositosis reaktif ditemukan dalam sejumlah situasi klinis termasuk penyakit menular seperti tuberkulosis paru. Trombositosis TB paru merupakan indeks hematologi yang penting dan fitur biasa dalam penilaian prognosis penyakit. ${ }^{5,9}$ Trombositopenia pada TB biasanya adalah komplikasi dari terapi, Rifampin telah diketahui sebagai penyebab trombositopenia. ${ }^{10}$

Berdasarkan latar belakang tersebut, peneliti tertarik untuk melakukan penelitian mengenai gambaran kadar hemoglobin dan trombosit pada penderita tuberkulosis paru di RSUP Prof. Dr. R. D. Kandou Manado.

\section{METODE PENELITIAN}

Penelitian ini menggunakan metode deskriptif retrospektif. Data yang digunakan merupakan data sekunder dari catatan medis penderita TB paru di RSUP Prof. Dr. R. D. Kandou Manado Periode Januari 2014 - Desember 2014. Sampel penelitian ialah seluruh pasien TB paru yang memenuhi kriteria inklusi dan eksklusi yang dirawat jalan di RSUP Prof. Dr. R. D. Kandou Manado periode Januari 2014 - Desember 2014. Yang termasuk kriteria inklusi pada penelitian ini adalah pasien TB paru BTA (+) kasus baru yang menjalani pemeriksaan laboratorium darah lengkap, belum mengkonsumsi OAT (Obat Anti Tuberkulosis), pasien rawat inap serta pasien $\geq 18$ tahun. Yang termasuk kriteria eksklusi pada penelitian ini adalah pasien hamil dan data yang tidak terbaca atau hilang. 


\section{HASIL PENELITIAN}

Berdasarkan penelitian yang dilaksanakan di instalasi rekam medik RSUP Prof. Dr. R. D. Kandou Manado didapatkan jumlah pasien sebanyak 250 penderita Tuberkulosis paru dalam data rekam medik dan dari data rekam medik yang memenuhi kriteria adalah 67 penderita TB paru.

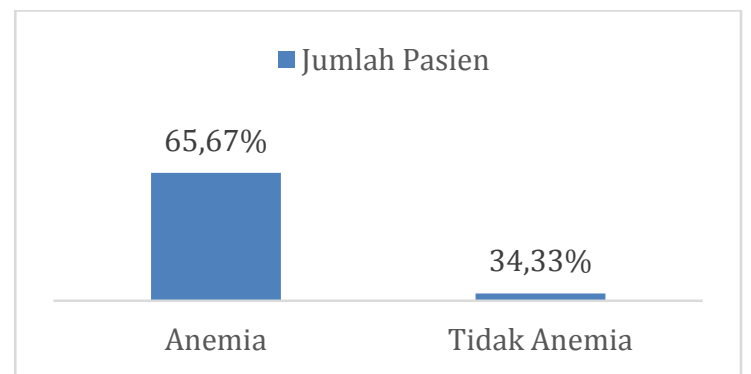

Gambar 1. Diagram distribusi pasien TB paru berdasarkan kadar hemoglobin

Berdasarkan hasil pemeriksaan laboratorium, jumlah pasien dengan kadar hemoglobin dibawah nilai normal atau anemia sebanyak 44 pasien $(65,67 \%)$ dansebanyak 23 pasien (34,33\%) tidak mengalami anemia.

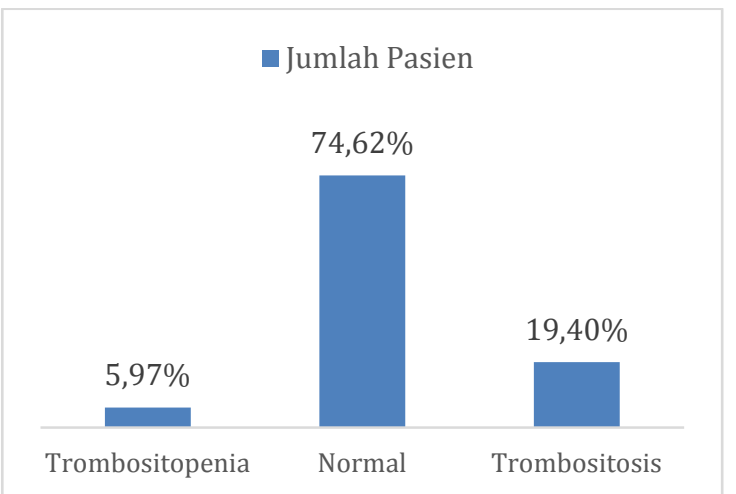

\section{Gambar 2. Diagram distribusi pasien TB paru berdasarkan jumlah trombosit}

Dari gambar 2, jumlah pasien yang mengalami trombositopenia sebanyak 4 pasien (5,97\%), pasien dengan kadar trombosit normal sebanyak 50 pasien (74,62\%), dan yang mengalami trombositosis sebanyak 13 pasien (19,40\%).

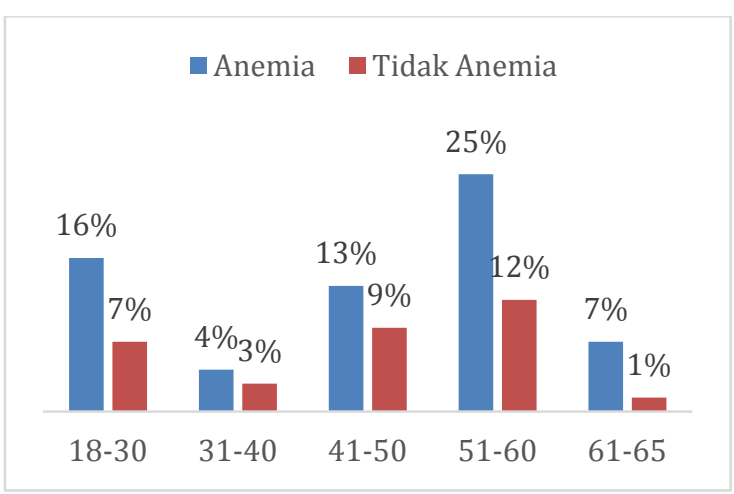

Gambar 3. Diagram distribusi kadar hemoglobin berdasarkan usia

Berdasarkan kelompok usia sesuai gambar 3 didapatkan kadar $\mathrm{Hb}$ yang rendah atau anemia terbanyak pada kelompok usia 51-60 sejumlah 17 kasus (25\%), kemudian kelompok usia 18-30 dengan jumlah 11 kasus (16\%), dan kelompok usia 41-50 dengan jumlah 9 kasus (13\%).

arombositopenia $\square$ Normal $\square$ Trombositosis

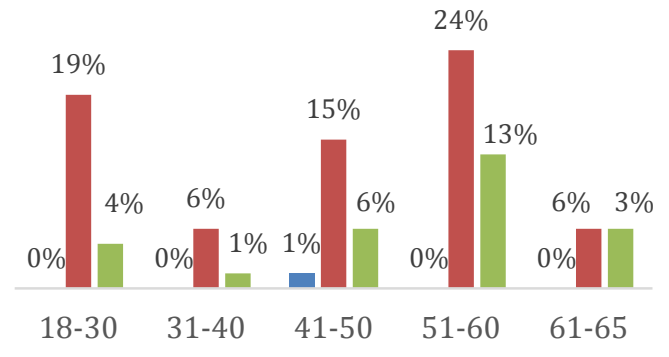

Gambar 4. Diagram distribusi jumlah trombosit berdasarkan usia

Berdasarkan kelompok usia sesuai gambar 4 didapatkan jumlah trombosit yang normal terbanyak pada kelompok usia 51-60 sejumlah 16 kasus (24\%), kemudian kelompok usia 18-30 dengan jumlah 13 kasus (19\%), dan kelompok usia 41-50 dengan jumlah 10 kasus (15\%). 


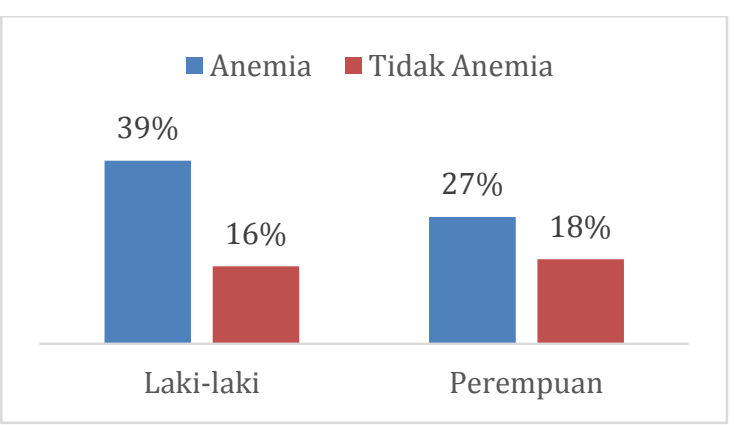

Gambar 5. Distribusi kadar hemoglobin berdasarkan jenis kelamin

Berdasarkan gambar 5, dapat dilihat bahwa pasien laki-laki yang mengalami anemia adalah yang terbanyak dengan jumlah 26 kasus (39\%) dan pasien perempuan sejumlah 18 kasus (27\%).

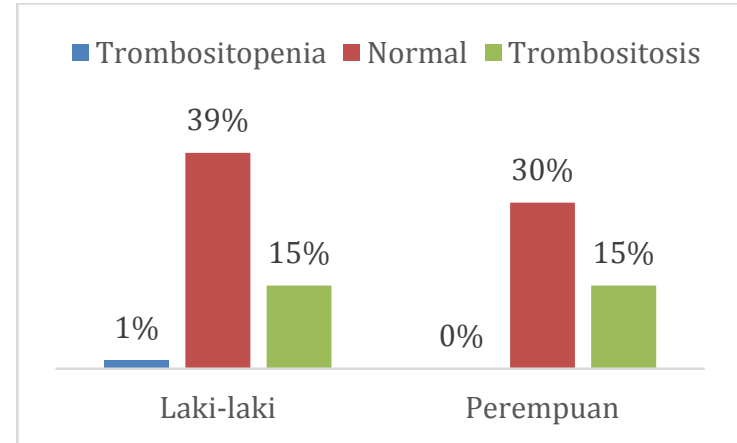

Gambar 6. Distribusi jumlah trombosit berdasarkan jenis kelamin

Berdasarkan gambar 6, dapat dilihat bahwa jumlah trombosit normal adalah yang terbanyak dengan jumlah 26 kasus (39\%) pada laki-laki dan 20 kasus (30\%) pada perempuan. Didapatkan juga trombositosis dengan hasil yang sama yakni masing-masing 10 kasus (15\%).

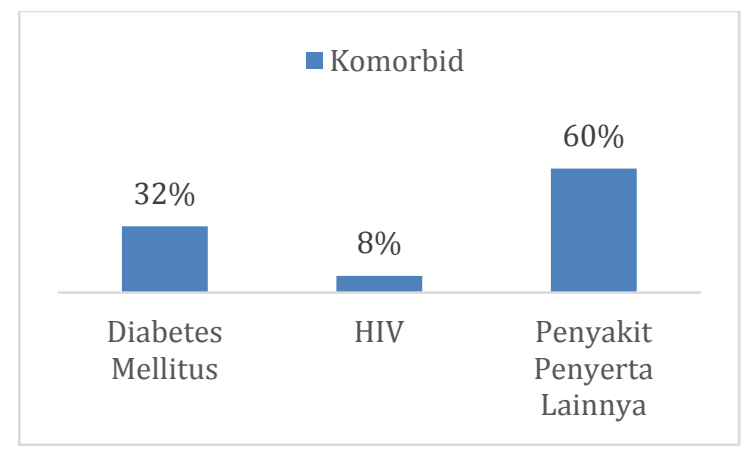

Gambar 7. Distribusi pasien TB paru berdasarkan komorbid
Berdasarkan komorbid, dari penelitian ditemukan bahwa pasien yang mengalami diabetes mellitus 16 pasien (32\%), HIV sebanyak 4 pasien (8\%), dan penyakit penyerta lainnya sebanyak 30 pasien (60\%).

\section{BAHASAN}

Kadar Hemoglobin merupakan indikator untuk menentukan seseorang menderita anemia atau tidak. Pada Gambar 1 dapat dilihat distribusi Hemoglobin pada pasien TB paru terdapat 44 pasien $(65,67 \%)$ dengan kadar $\mathrm{Hb}$ dibawah normal atau anemia. Pada Gambar 5 pasien laki-laki sebanyak 26 pasien (39\%) dan perempuan 18 pasien (27\%) mengalami anemia. Hal ini sejalan dengan penelitian yang dilakukan Sei Won Lee dkk, dari 281 pasien (31,9\%) yang didapati anemia, 133 pasien $(28,2 \%)$ adalah laki-laki dan 148 pasien (36,3\%) adalah perempuan. Supresi eritropoiesis oleh media inflamasi adalah faktor penyebab anemia dan defisiensi nutrisi dapat memperburuk anemia. Menurut Hiswani yang dikutip dari WHO, penderita TB paru cenderung lebih tinggi daripada laki-laki dibandingkan perempuan. Pada jenis kelamin laki-laki penyakit ini lebih tinggi karena merokok tembakau dan minum alcohol sehingga menurunkan sistem pertahanan tubuh, sehingga lebih mudah terpapar agen penyebab TB paru. ${ }^{11}$

Pada penelitian yang dilaksanakan di RSUP Prof. Dr. R. D. Kandou Manado pada tahun 2010, didapati jumlah pasien yang didiagnosis awal dengan tersangka TB paru sebanyak 83 pasien. Pada penelitian Panelewen PT, menurut distribusi umur pada laki-laki dan perempuan insiden terbanyak pada golongan umur 46-60 tahun yaitu 9 pasien (20,93\%) jenis kelamin laki-laki dan 7 pasien $(16,28 \%)$ jenis kelamin perempuan. Kelompok usia 51-60 pada Gambar 3 dan Gambar 4adalah kelompok usia terbanyak dengan jumlah 17 kasus (25\%) dan 16 kasus (24\%). Menurut Manalu HSP, pada usia lanjut lebih dari 55 tahun sistem 
imunologis seseorang menurun, sehingga sangat rentan terhadap berbagai penyakit. ${ }^{12,13}$

Kadar Trombosit merupakan indeks hematologi yang penting dan fitur biasa dalam penilaian prognosis penyakit. Pada Gambar 2 dan Gambar 6dapat dilihat distribusi kadar trombosit pada TB paru sebagian besar hasilnya normal sebanyak 50 pasien (74,62\%), tetapi masih ditemukan trombositopenia sebanyak 4 pasien (5,97\%) dan trombositosis sebanyak 13 pasien (19,40\%). Berdasarkan penelitian yang dilakukan oleh Unsal E dkk, dari 62 pasien yang terdiagnosis TB paru, 27 pasien $(43,54 \%)$ dengan kadar trombosit normal dan 35 pasien dengan trombositosis. Pada sejumlah kasus infeksi dan inflamasi, trombositosis reaktif sering ditemukan sebagai respon sistem inflamasi. Berdasarkan penelitian yang dilakukan Oehadian A, 87,5\% pasien dengan trombosit normal dan $12,5 \%$ pasien trombositopeni menyatakan kelainan hematologi dapat disebabkan karena proses infeksi tuberkulosis atau kelainan dasar hematologis yang sudah ada sebelumnya. ${ }^{14}$

Pada Gambar 7menunjukkan mengenai penyakit penyerta pada pasien TB paru. Menurut data yang berhasil dikumpulkan dari Rekam Medik RSUP Prof Dr. R. D. Kandou Manado, penyakit penyerta yang paling sering ditemukan adalah Diabetes Melitus dengan jumlah 16 pasien (32\%), dan HIV sebanyak 4 pasien(8\%). Yang dimaksud penyakit penyerta lainnya antara lain sindrom dyspepsia, ISK, CKD, Gastritis Akut, dan lain-lain. Berdasarkan penelitian Widyasari $\mathrm{RN}$, menemukan adanya hubungan riwayat penyakit penyerta dengan kejadian TB paru di wilayah Semarang Utara. ${ }^{15}$

\section{SIMPULAN}

Kadar Hemoglobin pada penderita TB paru ditemukan terbanyak $(65,67 \%)$ anemia. Jumlah trombosit pada penderita TB paru ditemukan terbanyak (74,62\%) dengan jumlah trombosit normal.

\section{DAFTAR PUSTAKA}

1. Saputra L. Organ System: Visual Nursing Respiratorik. Edisi ke-1. Tangerang: Binarupa Aksara 2014. h. 97.

2. World Health Organization (WHO). Global Tuberculosis Report 2014. 2014 Aug [cited 2015 Sep 25]. Available from:http://www.who.int/about/licensin g/copyright_form/en/index.html

3. Badan Penelitian dan Pengembangan Kesehatan. Riskesdas 2013. 1 Des 2013 [diakses 25 Sep 2015].Available from: http://www.depkes.go.id/resources/dow nload/general/Hasil\%20Riskesdas\%202 013.pdf

4. Hoffbrand AV, Moss PAH. Eritropoiesis dan aspek umum anemia. Dalam: Sandra F, editor. Kapita selekta hematologi. Edisi ke-6. Jakarta: EGC; 2013. h. 16-21.

5. Al-muhammadi MO, Al-shammery HG. Studying some hematological changes in patients with tuberculosis in Babylon Governorate. Med J Babylon. 2014; 8: 608-17.

6. Devi U, Rao M, Srivastava VK, Rath PK, Das BS. Effect of iron supplementation on mild to moderate anaemia in pulmonary tuberculosis. $\mathrm{Br}$ J Nutr. 2003; 90: 541-50.

7. Al-Omar IA, Al-Ashban RM, Shah AH. Hematological abnormalities in Saudis suffering from pulmonary tuberculosis and their response to the treatment. Research J pharmacology. 2009; 3: 7885.

8. Oesman F, Setiabudi RD. Fisiologi hemostasis dan fibrinolisis. Dalam: Setiabudy RD. Hemostasis dan Trombosis. Edisi ke-3. Jakarta: FK UI; 2007. h. 2

9. Unsal E, Aksaray S, Koksal D, Sipit T. Potential role of interleukin 6 in reactive thrombocytosis acute phase response in pulmonary tuberculosis. Postgrad Med J. 2005; 81: 604-7.

10. Oyer RA, Schlossberg D. Hematologic Changes in Tuberculosis. In: Schlossberg D. Tuberculosis. $3^{\text {rd }}$ Ed. 
Philadelphia: Springer-Verlag; 1994. p. 257-9

11. Hiswani M. Tuberkulosis Merupakan Penyakit Infeksi yang Masih Menjadi Masalah Kesehatan Masyarakat [disertasi]. [Medan]: FK USU; 2009

12. Panelewen PT. Profil Anemia Pada Penderita Tuberkulosis Paru di RSUP Prof. Dr. R. D. Kandou Manado [skripsi]. [Manado]: FK UNSRAT; 2010

13. Manalu HSP. Faktor-faktor yang mempengaruhi kejadian TB Paru dan Upaya Penanggulangannya. Jurnal Ekologi Kesehatan. 2010; 9: 1343

14. Oehadian A. Aspek Hematologi Tuberkulosis [disertasi]. [Bandung]: FK UNPAD; 2003

15. Widyasari RN. Hubungan Antara Jenis Kepribadian, Riwayat Diabetes Melitus dan Riwayat Paparan dengan Kejadian TB Paru Dewasa di Wilayah Kecamatan Semarang Utara [disertasi]. [Medan]: FKM UNDIP; 2013 